\title{
The relationship between serum urea levels and dietary nitrogen utilization in young men
}

\author{
BY YVONNE S. M. TAYLOR, N. S. SCRIMSHAW AND \\ V. R. YOUNG \\ Department of Nutrition and Food Science, Massachusetts Institute of \\ Technology, Cambridge, Massachusetts о2г39, USA \\ (Received I6 December I973-Accepted I5 February 1974)
}

\begin{abstract}
I. Results from metabolic balance studies in young adult men were examined for the relationships between the concentration of serum urea (SUN) and the efficiency of dietary nitrogen utilization. A total of 23 I separate balance periods were included in the analysis. Net protein utilization (NPU) was used as an index of dietary protein quality.

2. Protein intake ranged from $0.27-0.73 \mathrm{~g} / \mathrm{kg}$ body-weight per $\mathrm{d}$ in the various experiments. There was a highly significant negative correlation between NPU and urea levels. The relationship was: $\mathrm{NPU}=\mathrm{I} \cdot 23-0.029 \times \mathrm{SUN}(\mathrm{mmol} / \mathrm{l})(r=-0.89)$.

3. These results are considered in relation to the evaluation of protein quality in adult humans.
\end{abstract}

On the basis of studies in rats, Eggum (1970, 1973) has proposed that blood urea levels determined under well-defined feeding conditions could provide a rapid and accurate method for evaluating dietary protein. Because this method would be convenient for clinical studies, we have measured the levels of serum urea (SUN) of young men studied in metabolic balance experiments and given various protein sources and levels of nitrogen intake. This report summarizes our findings and assesses the possible utility of blood urea levels for evaluation of dietary protein quality and $\mathrm{N}$ utilization in human feeding.

\section{EXPERIMENTAL}

Subjects. The subjects were male students of Massachusetts Institute of Technology who carried out their usual daily activities while participating in the experiments. They ranged in age from I 8 to 26 years and weighed from 57 to $88 \mathrm{~kg}$. All were in good health as indicated by medical history, physical examination, urinalysis, and standard haematological and clinical chemistry procedures.

Diets. The various sources and levels of dietary protein intake listed in Table I provided either the entire or major portion of daily protein intake. Diet periods were usually of ${ }_{15} \mathrm{~d}$ duration, and the subjects received four equal meals at $08.00,12.00$, I7.00-18.00, and 21.00-22.00 hours, unless otherwise stated. The total energy intake was estimated to be sufficient to maintain body-weight (adequate intake) or $80 \%$ of this level (restricted intake). The general composition of the diets was similar to those previously described by Young, Taylor, Rand \& Scrimshaw (1973) and Scrimshaw, Taylor \& Young (1973), including non-protein energy sources, and mineral and vitamin supplements (Young et al. r973).

Balance periods. Complete $24 \mathrm{~h}$ urine and faecal collections were made throughout 
Table I. Experiments to evaluate the relationship between serum urea concentration and estimated dietary protein quality in young men

\begin{tabular}{|c|c|c|c|}
\hline Experiment* & $\begin{array}{c}\text { Source of } \\
\text { dietary protein }\end{array}$ & $\begin{array}{l}\text { Protein intakell } \\
(\mathrm{g} / \mathrm{kg} \text { per } \mathrm{d})\end{array}$ & $\begin{array}{l}\text { No. subjects } \\
\text { studied }\end{array}$ \\
\hline I & Wheat gluten & 0.27 & 6 \\
\hline 2 & Wheat gluten & 0.73 & 8 \\
\hline 3 & Chick-pea & 0.27 & 7 \\
\hline 4 & Chick-pea and rice & 0.65 & 8 \\
\hline 5 & Dried skim milk (DSM) & 0.5 & 7 \\
\hline 6 & DSM & 0.4 & 7 \\
\hline $7 a$ & $\begin{array}{l}\text { Wheat gluten and chick-peaf } \\
\text { Wheat gluten, chick-pea }\end{array}$ & 0.2 & 6 \\
\hline & $\begin{array}{l}\text { Wheat gluten, chick-pea } \\
\text { and DSM }\end{array}$ & 0.4 & 6 \\
\hline$c$ & $\begin{array}{l}\text { Wheat gluten, chick-pea } \\
\text { and DSM with } \\
\text { nonspecific N\$ }\end{array}$ & 0.4 & 6 \\
\hline $8 a$ & Whole dried egg & 0.2 & I I \\
\hline$b$ & Whole dried egg & 0.3 & I I \\
\hline$c$ & Whole dried egg & 0.4 & 8 \\
\hline$d$ & Whole dried egg & 0.5 & I I \\
\hline
\end{tabular}

* In Expts $I$ and 2 the effects of lysine supplementation and of adequate or restricted energy intakes on nitrogen utilization were studied (for experimental details, see Scrimshaw et al. (1973)). Expts 3 and 4 were of comparable design to Expts $I$ and 2 except that L-methionine supplementation was studied. In Expts 5 and 6 the effects of level of energy intake and of distribution of meals on $N$ utilization were evaluated (for experimental details, see Taylor, Young, Murray, Pencharz \& Scrimshaw (1973)). Details of Expt 8 are given in Young et al. (1973).

+ Ratio as source of protein $70: 30$.

\pm Ratio as source of protein 85: 15 .

$\S 200 \mathrm{~g} \mathrm{DSM}$ protein $/ \mathrm{kg}$ diet was isonitrogenously replaced by a mixture of glycine and diammonium citrate.

II $\mathrm{N} \times 6.25$.

the experimental diet periods. Urinary $\mathrm{N}$ output during the final 5 or ro $\mathrm{d}$ of each dietary period and faecal $\mathrm{N}$ output during the final ro $\mathrm{d}$ was used for the $\mathrm{N}$ balance determinations. 'The derived estimates of protein quality, namely, net protein utilization (NPU) and biological value (BV) were calculated (Young, Özalp, Cholakos \& Scrimshaw, 197I), assuming mean obligatory urine and faecal losses to be $37 \cdot 1$ and $8.8 \mathrm{mg} \mathrm{N} / \mathrm{kg}$ body-weight per d, respectively (Scrimshaw, Hussein, Murray, Rand \& Young, 1972). Because obligatory $\mathrm{N}$ losses are measured at adequate energy intakes, the values do not strictly apply to subjects consuming inadequate energy. However, the same values have been applied throughout, to provide relative estimates of the apparent efficiency of dietary $\mathrm{N}$ utilization in young adult men. The values for $\mathrm{BV}$ and NPU are expressed here as ratios.

Analyses. Faeces were pooled as previously described (Young, Hussein, Murray \& Scrimshaw, 197I). Urine, faecal and dietary $\mathrm{N}$ were determined according to the method of Munro \& Fleck (1969). Venous blood samples were taken at the end of each dietary period. SUN concentration (Technicon Instruments Corporation, 1967) was measured either in samples drawn after an overnight ( $1 \circ \mathrm{h}$ ) fast at 08.00 or at I2.00 hours, just prior to the lunchtime meal. Under the conditions of relatively lowprotein intakes, there was no consistent difference between SUN levels at these two times. 


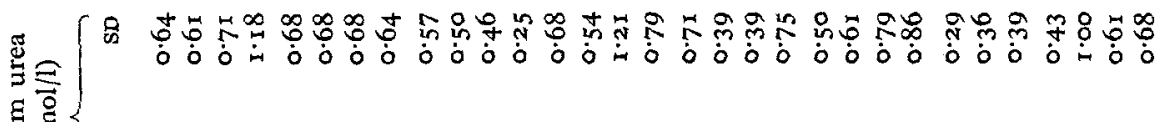

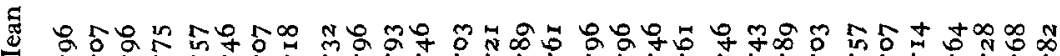
in în

$\overleftrightarrow{\text { \$ }}$

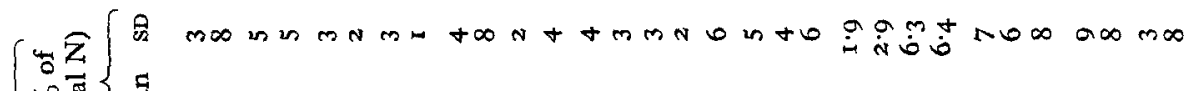

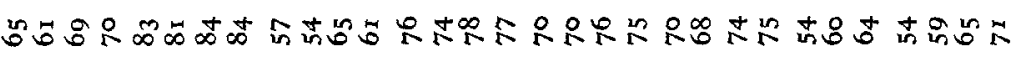

里

)

$\rightarrow 2$

골

量

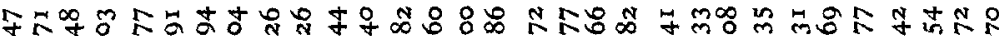
ó

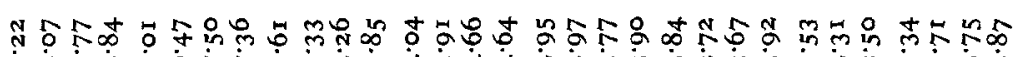

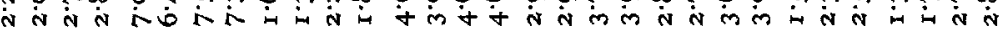

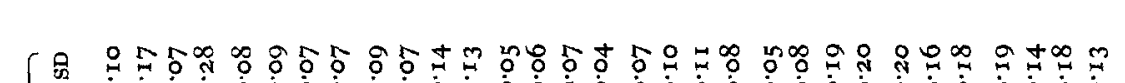
总

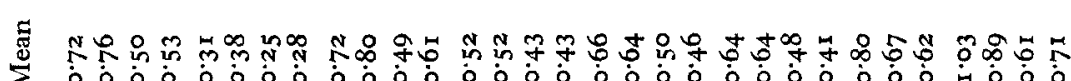

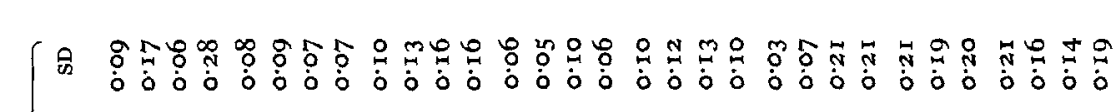
甼

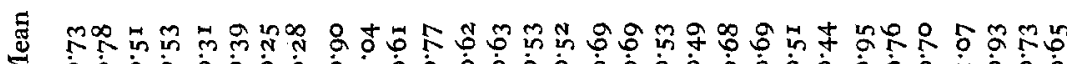

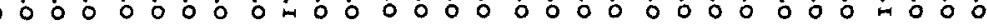
z

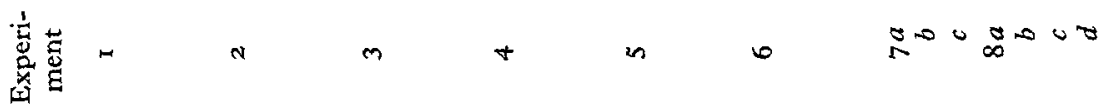




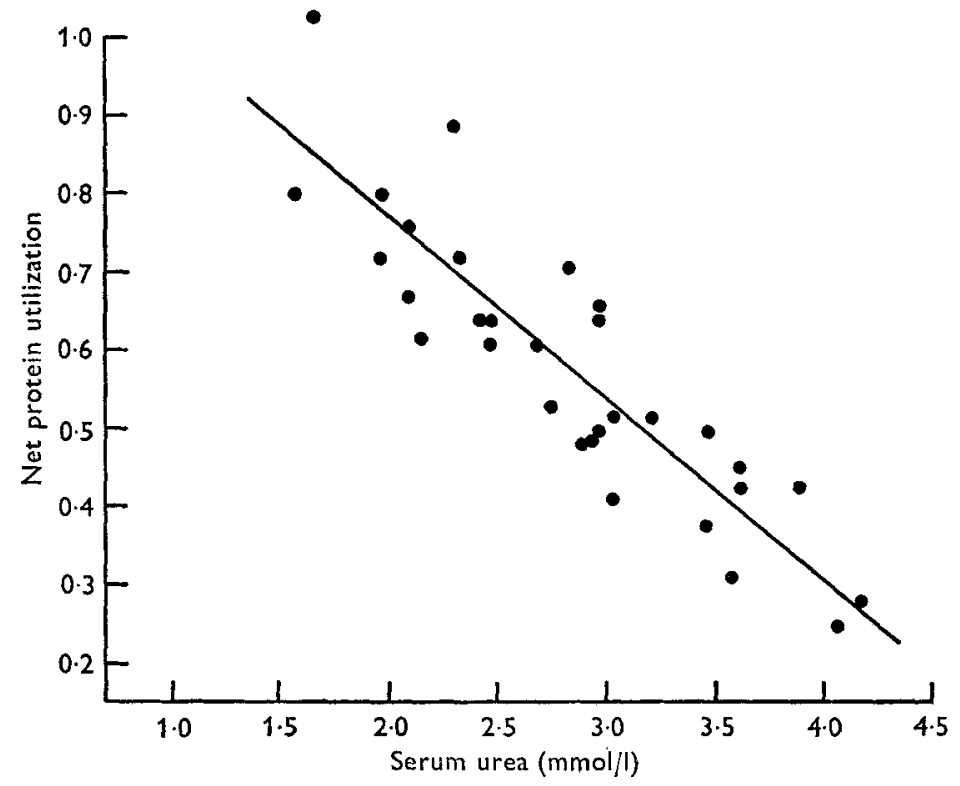

Fig. I. Relationship between net protein utilization (NPU) and serum urea concentration in young men studied in thirty-one separate dietary periods. The regression equation is: $\mathrm{NPU}=$ $\mathrm{I} \cdot 23-0.029 \times$ serum urea $(\mathrm{mmol} / \mathrm{l}) . s=0.082 ; s_{0}=0.0027 ; r=-0.89$.

\section{RESULTS AND DISCUSSION}

Table 2 summarizes the mean $\mathrm{N}$ balance and SUN values for the various diets and experimental groups. These results reveal a close relationship between SUN levels and urinary urea- $\mathrm{N}$ excretion, expressed as $\mathrm{g} / \mathrm{d}$ or as the percentage of total urinary $\mathrm{N}$ output. The correlations $(r)$ for the diet groups are 0.87 and 0.93 , respectively. The relationship between SUN and the indicators of efficiency of N utilization (NPU and Bv) was inverse; for the diet groups the correlations are -0.89 and -0.88 , respectively. Both were statistically significant $(P<0.00 \mathrm{r})$.

The regression of NPU on SUN for the thirty-one diet groups is shown in Fig. I. The results shown in this figure are based on mean values for each diet group. Using individual values for each of the $23 \mathrm{I}$ balance determinations, the correlation between SUN levels and NPU and BV was -0.66 or -0.67 , respectively. Both correlation coefficients were highly significant $(P<0.001)$. Within each diet, the correlation between NPU and SUN was usually non-significant for the few subjects studied.

The estimated NPU and BV depends, in part, upon the amino acid composition and levels of total protein and energy intake. It is usual to standardize diets for the latter two variables when evaluating a test protein. Although in the present experiments protein intake ranged from $0.27^{-0} \cdot 7 \mathrm{~g} / \mathrm{kg}$ per $\mathrm{d}$, we find that the apparent efficiency of $\mathrm{N}$ utilization in adult men, as estimated by calculation of NPU or BV, is significantly and negatively correlated with the SUN concentration. However, there was no statistically significant relationship between the absolute $\mathrm{N}$-balance values and SUN values. On the other hand, for healthy individuals receiving an adequate energy intake, SUN concentration shows a positive relationship with changes in protein in- 
take above requirement levels (Addis, Barrett, Poo \& Yuen, I947; Kies \& Fox, 1972). This provides a rationale for use of SUN levels in population surveys on protein nutritional status (e.g. Arroyave, i96r).

It has been suggested that SUN levels can be used as an indicator of the protein value of the diet in nutrition surveys, but our experience under uncontrolled conditions indicates that they are an unreliable guide since good quality, high-protein diets as well as poor-quality diets will result in relatively high SUN levels. The same reservation would apply to the ratio of urea $\mathrm{N}$ : creatinine as an indicator of protein intake and nutritional status.

The N-balance method is time-consuming, inconvenient, and prone to systematic technical errors. New approaches are needed in the study of human protein nutrition. The present findings confirm those of Eggum (1970, 1973) and indicate that under appropriately controlled conditions SUN may be of value in estimating the protein quality of a diet, giving results comparable to those obtained with the $\mathrm{N}$-balance method. Presumably experimental conditions can be optimized so that SUN can be used for this purpose in human subjects.

These studies were largely supported by a grant from the USPHS (AM-I $5^{8} 5^{6}$ ) and a contract (AID/csd-2808) with the Agency for International Development, Department of State, Washington DC. The experiments made use of the facilities of the M.I.T. Clinical Research Center, supported by Grant RR-88 from the General Clinical Research Centers Program of the Division of Resources, National Institute of Health, Bethesda, Maryland 20014, USA. This is publication No. 2297 from the Department of Nutrition and Food Science, M.I.T.

\section{REFERENCES}

Addis, T., Barrett, E., Poo, L. J. \& Yuen, D. W. (1947). F. clin. Invest. 26, 869.

Arroyave, G. (r96r). Fedn Proc. Fedn Am. Socs exp. Biol. 20, 39.

Eggum, B. O. (1970). Br. F. Nutr. 24, 983.

Eggum, B. O. (1973). In Proteins in Human Nutrition p. $3^{17}$ [J. W. G. Porter and B. A. Rolls, editors]. New York: Academic Press.

Kies, C. \& Fox, H. M. (1972).F. Nutr. 102, 757.

Munro, H. N. \& Fleck, A. (1969). In Mammalian Protein Metabolism Vol. 3, p. 435 [H. N. Munro, editor]. New York: Academic Press.

Scrimshaw, N. S., Hussein, M. A., Murray, E., Rand, W. M. \& Young, V. R. (I972). F. Nutr. ro2, 1595 .

Scrimshaw, N. S., Taylor, Y. S. M. \& Young, V. R. (1973). Am. F. clin. Nutr. 26, 965.

Taylor, Y. S. M., Young, V. R., Murray, E., Pencharz, P. B. \& Scrimshaw, N. S. (r973). Am. F. clin. Nutr. 26, 1216.

Technicon Instruments Corporation (1967). Technicon AutoAnalyzer Methodology Publication N-Ic. Tarrytown, New York: Technicon Instruments Corporation.

Young, V. R., Özalp, I., Cholakos, B. \& Scrimshaw, N. S. (1971). F. Nutr. rox, 1475.

Young, V. R., Hussein, M. A., Murray, E. \& Scrimshaw, N. S. (1971). F. Nutr. ror, 45.

Young, V. R., Taylor, Y. S. M., Rand, W. M. \& Scrimshaw, N. S. (1973). F. Nutr. ro3, I 64. 